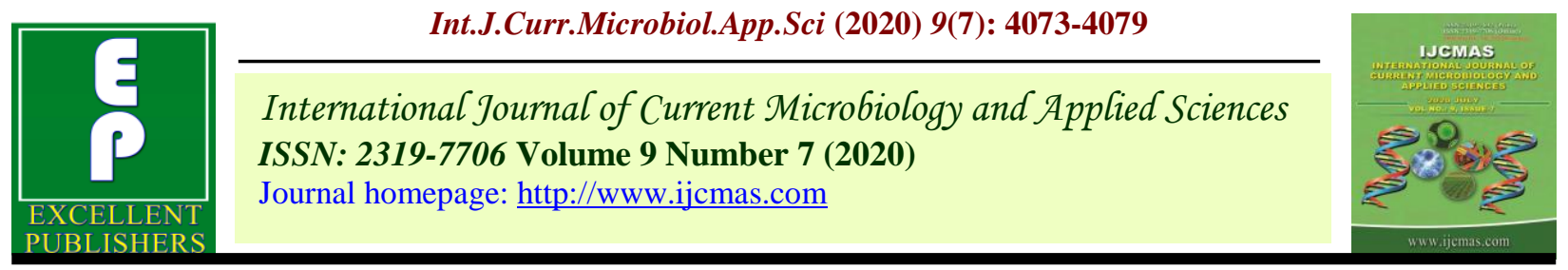

Original Research Article

https://doi.org/10.20546/ijcmas.2020.907.478

\title{
Forms and Distribution of Sulphur in Direct Seeded Paddy Growing Soils of Kalaghatagi Taluk of Dharwad District, India
}

\author{
D. Dhanalakshmi* and K. K. Math \\ Department of Soil Science and Agricultural Chemistry, College of Agriculture University of \\ Agricultural Sciences, Dharwad-580 005, Karnataka, India \\ *Corresponding author
}

\begin{abstract}
A B S T R A C T
Keywords

Sulphur, Sulphur forms, Direct seeded paddy soils

Article Info

Accepted:

25 June 2020

Available Online:

10 July 2020

Sulphur (S) deficiency is widespread in Indian soils and is been emerging as a major limitation for enhancing productivity. Soils of Karnataka are largely deficient in sulphur (52\%). In this context, survey work was carried out during the year 2017 to know the status of sulphur and its forms and distribution in 90 soil samples from direct seeded paddy growing areas in 15 villages in Kalaghatagi Taluk of Dharwad district. Available sulphur status in soils ranged from 6.70 to $25.3 \mathrm{mg} \mathrm{kg}^{-1}$ and 42.2 per cent of the soil samples were deficient in available sulphur. The different forms of sulphur in these soils followed the order: Water soluble-sulphur < Sulphate-sulphur < Organically bound-sulphur $<$ Total-sulphur.
\end{abstract}

\section{Introduction}

Rice is the most important crop within the sector contributes for about 92 per cent of the total food grains produced in the country. In Dharwad district, it is grown over an area of 32,834 acre with a production of 35,398 tones and productivity of $1,135 \mathrm{~kg} \mathrm{ha}^{-1}$. It is extensively grown in Kalaghatgi Taluk and Mugad and rice is one of the major crops in Kalaghatagi Taluk in Dharwad.

Sulphur (S) is one of the most important nutrients for all plants and animals and is considered as the fourth major nutrient after nitrogen, phosphorous and potassium for agricultural crop production. It is involved in chlorophyll formation, activation of enzymes and is a part of vitamins biotin and thiamine. Sulphur exists in soil in both organic and inorganic forms, however the proportion of inorganic to organic sulphur depends on the soil type and depth and management practices. The inorganic forms of sulphur comprising of easily soluble sulphur and adsorbed sulphate are generally believed to be the immediate source of sulphur for plants uptake as reported by Kulhanek et al., (2011).

Different forms of sulphur include sulphate-S, water soluble-S, heat soluble-S, organic-S and total-S. Organic-S accounts for 70 to 99 per 
cent of total-S. The knowledge regarding the distribution of sulphur and their forms in soils helps in understanding the contribution of individual sulphur forms to plant availability. Status and distribution of soil sulphur in various pools has become a focal point of research for many years. The extent of the distribution of sulphur in different fractions plays a vital role in determining their availability to plants (Iyenger et al., 1981). In Sulphur deficiency is widespread in Indian soils and is major yield for limiting factor. Availability of sulphur to plants depends more on several factors like climate, vegetation, parent material, soil texture, and management practices (Ganeshamurthy et al., 1999). About 65.0 per cent of the soils in Dharwad district were deficient in sulphur. It is more likely these soils are low in plant available sulphur due to leaching losses caused by high rainfall. Thus, the current study was undertaken to determine the status and distribution of different forms of sulphur in direct seeded paddy growing soils in 15 villages of Kalaghatagi Taluk in Dharwad district.

\section{Materials and Methods}

\section{Site description}

The study area comprised Beguru, Bisaralli, Devikoppa, Dhulikoppa, Dummawada, Galagi, Halligeri, Hirehonnalli, Hulikoppa, Junjanabyla, Kalaghatagi, Karalakoppa, Sangameshwar, Sulikatte and Thambur villages of Kalaghatagi Taluk of Dharwad district. The sampling locations were marked by using GPS.

\section{Soil sampling and analysis}

To characterize the soil samples from direct seeded paddy growing soils, survey was conducted during kharif 2017 season before sowing of the crops and ninety (90) soil samples were collected randomly from the direct seeded paddy growing soils at depth of $0-20 \mathrm{~cm}$ from 15 villages of Kalaghatgi Taluk. Processed soil samples were analyzed for different forms of sulphur namely sulphate-sulphur, water soluble-sulphur, totalsulphur and organic-sulphur. Sulphatesulphur in soil was extracted with 0.15 per cent calcium chloride solution and determined by turbidimetry by using spectrophotometer at $420 \mathrm{~nm}$ (Sparks, 1996) and the results expressed in $\mathrm{mg} \mathrm{kg}^{-1}$. Total-sulphur content in soil samples was estimated by acid digestion method as given by Tabatabai (1982). Organic-sulphur content in the soil samples was computed by subtracting sulphatesulphur from total-sulphur.

\section{Results and Discussion}

Results indicated that sulphate-sulphur content in soil samples collected from the framers' fields of Beguru village ranged from 7.10 to $16.80 \mathrm{mg} \mathrm{kg}^{-1}$ with the average value of $11.64 \mathrm{mg} \mathrm{kg}^{-1}$ (Fig. 1 \& 3). Similarly, the water soluble-sulphur content in soils ranged from 2.41 to $7.00 \mathrm{mg} \mathrm{kg}^{-1}$, organic form of sulphur from 322.0 to $440.5 \mathrm{mg} \mathrm{kg}^{-1}$ and total-sulphur from 329.1 to $457.3 \mathrm{mg} \mathrm{kg}^{-1}$. In Bisaralli village, sulphate-sulphur, water soluble-sulphur and organically boundsulphur ranged from 7.90 to $19.2,2.67$ to 8.92 and 354.4 to $489.7 \mathrm{mg} \mathrm{kg}^{-1}$, respectively with the corresponding mean values of 13.54, 5.24 and $421.8 \mathrm{mg} \mathrm{kg}^{-1}$. The total-sulphur content in these soils varied from 353.3 to $508.9 \mathrm{mg}$ $\mathrm{kg}^{-1}$ with a mean value of $435.3 \mathrm{mg} \mathrm{kg}^{-1}$. It was noticed from Fig $1 \& 3$, sulphate-sulphur, water soluble-sulphur, organically boundsulphur and total-sulphur contents in the surface soil samples $(0-20 \mathrm{~cm})$ collected from the fields of Devikoppa village, respectively varied between 7.65 to $23.42,2.59$ to 10.20 , 340.0 to 576.3 and 347.7 to $599.7 \mathrm{mg} \mathrm{kg}^{-1}$ with $15.52,5.63,463.4$ and $478.9 \mathrm{mg} \mathrm{kg}^{-1}$ as their corresponding mean values. The total- 
sulphur content in the soil samples collected from the fields of Dhulikoppa village ranged from 337.2 to $469.9 \mathrm{mg} \mathrm{kg}^{-1}$ with the average value of $402.6 \mathrm{mg} \mathrm{kg}^{-1}$. The distribution of sulphate-sulphur, water soluble-sulphur and organically bound-sulphur in surface soil samples $(0-20 \mathrm{~cm})$ collected from the farmers' fields of Dhulikoppa village, respectively varied from 7.29 to $17.4,2.47$ to 6.30 and 329.9 to $452.5 \mathrm{mg} \mathrm{kg}^{-1}$ and 12.03 , 4.15 and $390.5 \mathrm{mg} \mathrm{kg}^{-1}$ as their corresponding mean values. The total content of sulphur in the surface layer soil samples $(0-20 \mathrm{~cm})$ collected from the farmers' fields of Dummawada village ranged from 368.8 to $496.9 \mathrm{mg} \mathrm{kg}^{-1}$ with the mean value of 426.5 $\mathrm{mg} \mathrm{kg}^{-1}$. Similarly, sulphate-sulphur, water soluble-sulphur and organically boundsulphur forms, respectively ranged from 8.25 to $18.6,4.60$ to 279.0 and 690.0 to $478.3 \mathrm{mg}$ $\mathrm{kg}^{-1}$ with $13.03,4.60$ and $413.5 \mathrm{mg} \mathrm{kg}^{-1}$ as their corresponding mean values (Fig.1 and $3)$.

The total-sulphur, sulphate-sulphur, water soluble-sulphur and organically boundsulphur forms in soil samples collected from paddy cultivated fields of Galagi village, respectively ranged from 321.4 to $617.5,6.70$ to $24.3,2.27$ to 11.2 and 314.7 to $593.3 \mathrm{mg}$ $\mathrm{kg}^{-1}$ with their corresponding mean values of $465.5,15.09,6.05$ and $450.4 \mathrm{mg} \mathrm{kg}^{-1}$. The sulphate-sulphur, water soluble-sulphur and organically bound-sulphur contents in surface soil samples $(0-20 \mathrm{~cm})$ collected from the farmer's fields of Halligeri village (Fig. 1 \& 3 ), respectively ranged from 6.52 to 16.25 , 2.21 to 8.52 and 304.1 to $429.9 \mathrm{mg} \mathrm{kg}^{-1}$ with their corresponding mean values of 11.56 , 5.41 and $378.8 \mathrm{mg} \mathrm{kg}^{-1}$. The total-sulphur content in the surface soil varied from 310.7 to $446.1 \mathrm{mg} \mathrm{kg}^{-1}$ with an average value of $390.4 \mathrm{mg} \mathrm{kg}^{-1}$. The four forms of sulphur namely sulphate-sulphur, water solublesulphur, organically bound-sulphur and totalsulphur contents in soil samples collected from the fields of Hirehonnalli village ranged from 6.96 to $23.31,2.36$ to $8.91,318.7$ to 574.1 and 325.7 to $597.4 \mathrm{mg} \mathrm{kg}^{-1}$, respectively and the mean values for the same four forms of sulphur were $14.874 .99,445.8$ and $460.7 \mathrm{mg} \mathrm{kg}^{-1}$ respectively. The total sulphur content in the surface layer soil samples collected from the farmers' fields of Hulikoppa village ranged from 347.7 to 638.9 $\mathrm{mg} \mathrm{kg}^{-1}$ with the average value of $489.2 \mathrm{mg}$ $\mathrm{kg}^{-1}$. Similarly, sulphate-sulphur, water soluble-sulphur and organically boundsulphur, respectively ranged from 7.59 to $25.25,2.57$ to 8.02 and 340.2 to $613.7 \mathrm{mg} \mathrm{kg}^{-1}$ with $15.96,5.07$ and $473.2 \mathrm{mg} \mathrm{kg}^{-1}$ as their corresponding mean values.

The total-sulphur content in soil samples collected from the fields of Junjanabyla village ranged from 344.5 to 520.0 with an average value of $402.6 \mathrm{mg} \mathrm{ka}^{-1}$. Similarly, the suplate-sulphur, water soluble-sulphur and organically bound-sulphur forms in the surface layer soils samples, respectively ranged from 7.52 to19.7, 2.28 to 7.50 and 337.0 to $500.3 \mathrm{mg} \mathrm{kg}^{-1}$ with the corresponding mean values of $12.03,4.15$ and $390.5 \mathrm{mg} \mathrm{kg}^{-1}$. The total-sulphur content in the surface layer soil samples collected from the farmers' fields of Kalaghatagi village ranged from 360.6 to $595.2 \mathrm{mg} \mathrm{kg}^{-1}$ with the average value of 426.5

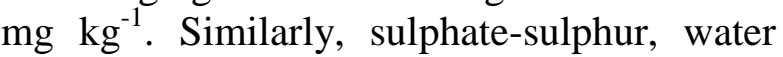
soluble-sulphur and organically boundsulphur, respectively ranged from 8.35 to $23.2,2.82$ to 8.35 and 348.4 to $572.0 \mathrm{mg} \mathrm{kg}^{-1}$ with $13.03,4.60$ and $413.5 \mathrm{mg} \mathrm{kg}^{-1}$ as their corresponding mean values.

The results indicated that the total-sulphur, sulphate-sulphur, water soluble-sulphur and organically bound-sulphur forms in soil samples collected from paddy cultivated fields of Galagi village, respectively ranged from 334.6 to $540.8,7.21$ to $20.7,2.44$ to 6.12 and 327.4 to $520.1 \mathrm{mg} \mathrm{kg}^{-1}$ with their corresponding mean values of 465.5, 15.09, 
6.05 and $450.4 \mathrm{mg} \mathrm{kg}^{-1}$. The total-sulphur content in the soil samples collected from the fields of Sangameshwar village ranged from 326.2 to $552.2 \mathrm{mg} \mathrm{kg}^{-1}$ with the average value of $437.1 \mathrm{mg} \mathrm{kg}^{-1}$. The distribution of sulphatesulphur, water soluble-sulphur and organically bound-sulphur in surface soil samples collected from the farmers' fields of Sangameshwar village, respectively varied from 6.85 to $21.20,2.32$ to 7.30 and 13.68 , 4.67 to $423.4 \mathrm{mg} \mathrm{kg}^{-1} \mathrm{mg} \mathrm{kg}$ as their corresponding mean values. The different forms of sulphur such as sulphate-sulphur, water soluble-sulphur and organically boundsulphur and their distribution in surface layer soil samples collected from the fields of
Sulikatti village ranged from 8.31 to 23.03 , 1.24 to 5.87 and 361.3 to $568.3 \mathrm{mg} \mathrm{kg}^{-1}$ respectively with the corresponding mean values of $13.34,3.16$ and $427.2 \mathrm{mg} \mathrm{kg}^{-1}$. Sulphate-sulphur and water soluble-sulphur constituted 3.02 and 0.71 per cent of the total sulphur while 96.98 per cent of the totalsulphur was organically bound. The totalsulphur content in these soils varied from 374.1 to $591.4 \mathrm{mg} \mathrm{kg}^{-1}$ with a mean value of $440.5 \mathrm{mg} \mathrm{kg}^{-1}$. Among different fractions, the organically form of sulphur was the highest contributing about 96.09 to 96.57 per cent of total-sulphur whereas water-soluble fraction was the least contributing about 0.33 to 0.99 per cent of total- sulphur.

Fig.1 Available sulphur $\left(\mathrm{mg} \mathrm{kg}^{-1}\right)$ status in direct seeded paddy growing soils of Kalaghatagi Taluk

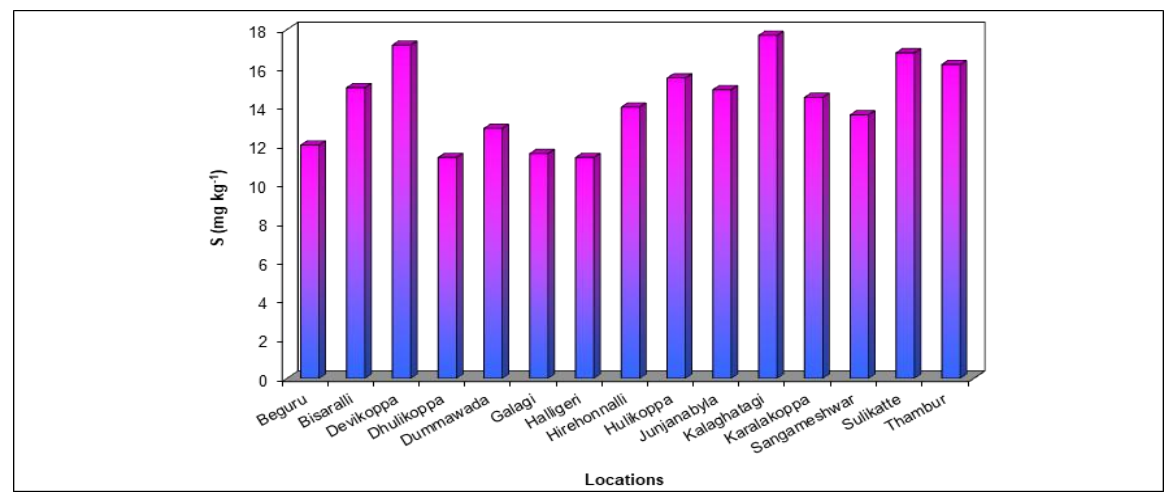

Fig.2 Per cent soil samples deficient in available sulphur in direct seeded paddy growing soils of soils of Kalaghatagi Taluk

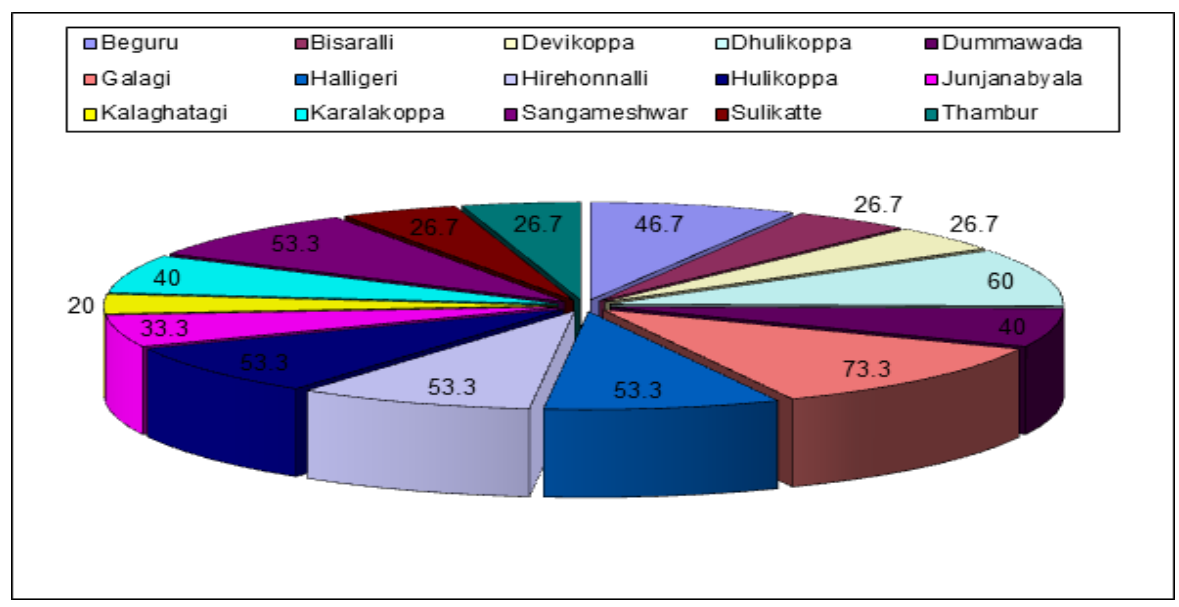


Fig.3 Forms and distribution of Sulphur in direct seeded paddy growing soils of Kalaghatagi Taluk

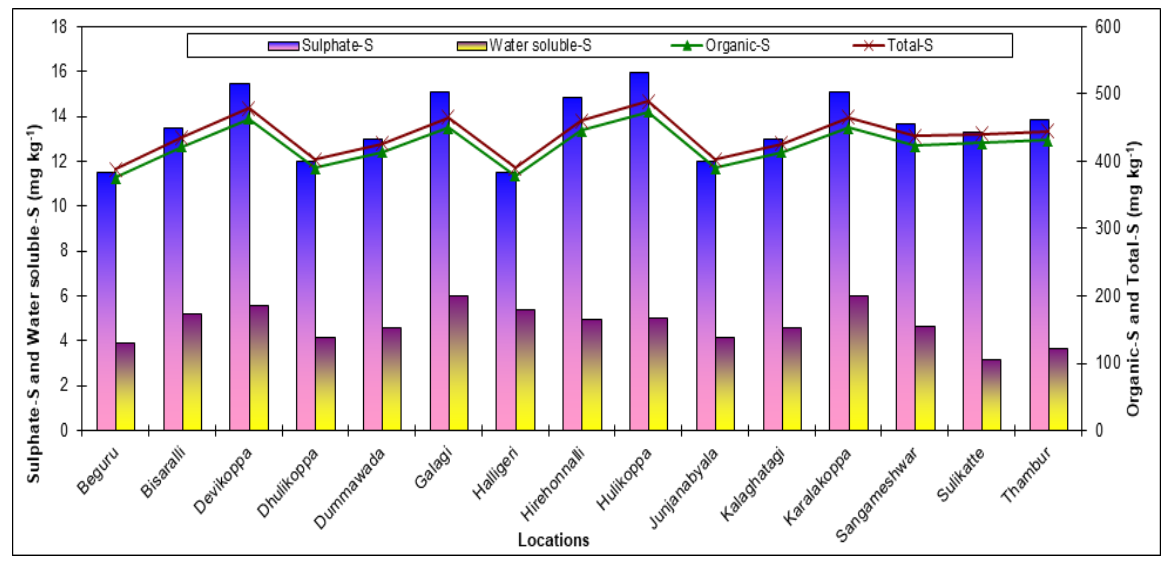

The total content of sulphur in the surface layer soil samples collected from the farmers' fields of Thambur village ranged from 336.5 to $582.2 \mathrm{mg} \mathrm{kg}^{-1}$ with the mean value of 445.0 $\mathrm{mg} \mathrm{kg}^{-1}$. Similarly, sulphate-sulphur, water soluble-sulphur and organically boundsulphur forms, respectively ranged from 7.05 to $22.60,2.39$ to 5.86 and 329.5 to $559.6 \mathrm{mg}$ $\mathrm{kg}^{-1}$ with $13.90,3.69$ and $431.5 \mathrm{mg} \mathrm{kg}^{-1}$ as their corresponding mean values and the above said fractions constituted about 3.12, 0.82 and 96.87 per cent of the total-sulphur. Among the different forms of sulphur, organically bound-sulphur was dominant one (96.11 to $97.91 \%$ of total-sulphur).

The available sulphur status in the surface $(0$ $20 \mathrm{~cm}$ ) soil samples in the study areas of Kalaghatgi taluk ranged from 6.70 to $25.3 \mathrm{mg}$ $\mathrm{kg}^{-1}$ with a mean value of $14.31 \mathrm{mg} \mathrm{kg}^{-1}$ (Fig. 1). Forty one point three zero per cent of the soil samples tested medium in available sulphur status and the values ranged from 10.2 to $19.9 \mathrm{mg} \mathrm{kg}^{-1}$, while 42.20 per cent of the samples tested were low (Fig. 2) and the values ranged from 6.70 to $9.96 \mathrm{mg} \mathrm{kg}^{-1}$. The lower available status of the sulphur in some of the soils might be attributed to non addition of the sulphur containing fertilizers and little or no addition of organic matter including organic manures and continuous mining of sulphur by crops (Patil et al., 2012). Further lower organic matter content $(<5.00 \mathrm{~g} / \mathrm{kg})$ was observed in these soils. Lower available sulphur status in these soils was attributed to lower organic carbon content. The lower available sulphur status in these soils might also be due to the higher $\mathrm{pH}$ in these soils. Shirgire et al., (2018) attributed higher $\mathrm{pH}$ values in soils for their lower available sulphur content in 200 surface soil samples collected from farmers' fields from Jamnagar district. The present investigations are in line with the findings of Paritosh et al., (2012).

The different forms of sulphur (Fig. 3) such as sulphate-sulphur, water soluble-sulphur and organically bound-sulphur and their distribution in the surface layer of soil samples collected from the farmers' fields of Kalaghtagi taluk ranged from 6.52 to 25.25 , 1.24 to 11.20 and 304.1 to $613.7 \mathrm{mg} \mathrm{kg}^{-1}$ respectively. Sulphate-sulphur and water soluble- sulphur constituted 3.10 and 1.05 per cent of the total sulphur while 96.89 per cent of the total sulphur was organically bound. Among the different forms, water soluble sulphur was found to be least $(1.05 \%$ of total sulphur). It might be due to the leaching losses of the water soluble-sulphur from the surface soil. Similar results were reported by Das et al., (2011) in Entisols of Assam and 
Sen et al., (2017) in Entisols, Inceptisols and Ultisols of Meghalaya the most dominant sulphur form in the study area was organically bound sulphur and it constituted 96.89 per cent of the total sulphur. It might be due to the intimate relationship with organic matter content and which helps to release of some organic acids due to microbial activity and that microbes play a critical role as a link in allowing plants to access soil organic-sulphur. These observations collaborate with the findings of Jat and Yadav (2006) in Jaipur district of Rajasthan. The total-sulphur content in these soil samples ranged from 310.7 to $638.9 \mathrm{mg} \mathrm{kg}^{-1}$ with an average value of $436.78 \mathrm{mg} \mathrm{kg}^{-1}$. Similarly, Sutariya et al., (2016) observed that the total-sulphur content varied between 176 to $522 \mathrm{mg} \mathrm{kg}^{-1}$. Similarly Narale et al., (2015) reported that totalsulphur, organic-sulphur, non-sulphatesulphur and water soluble-sulphur contents in Inceptisols, Entisols and Vertisols of Maharashtra varied from 163 to 2500,16 to 196, 61 to 2417 and 6 to $69 \mathrm{mg} \mathrm{kg}^{-1}$, respectively. Kajal et al., (2019) also reported that the content of total-S, organic-S, sulphate-sulphur, non-sulphate-sulphur and water soluble-sulphur ranged from 293 to $455,213.14$ to $312.34,7.65$ to $11.94,56.12$ to 137.91 and 3.45 to $8.12 \mathrm{mg} \mathrm{kg}^{-1}$ respectively, in Alfisols of Nagpur district.

Form the present study it can be concluded that 42.2 per cent of the soils were low in available sulphur and the values ranged from 6.70 to $25.3 \mathrm{mg} \mathrm{kg}^{-1}$. The different forms of sulphur in direct seeded paddy growing soil samples of study area followed the order of preponderance: Water soluble-S (1.20 -11.2 $\left.\mathrm{mg} \mathrm{kg}^{-1}\right)<$ Sulphate-S $\left(6.52-25.3 \mathrm{mg} \mathrm{kg}^{-1}\right)<$ Organically bound-S (304.1-613.7 $\left.\mathrm{mg} \mathrm{kg}^{-1}\right)<$ Total-S (310.7-638.9 $\mathrm{mg} \mathrm{kg}^{-1}$ ). Among the different forms of sulphur, organically bound form constituted 96.09 to 97.85 per cent of the total-sulphur. Organically-sulphur constituted 96.09 to 97.85 per cent of total sulphur and is a major source to available pool of sulphur in these soils.

\section{References}

Das, K. N., Basumatary, A. and Borkotoki, B., 2011, Interrelationship of forms of sulphur and boron with its availability indices and soil properties in Entisols of Assam. J. Indian Soc. Soil Sci., 59(2): 134-140.

Ganeshamurthy, A.N.; Saha, J.K. Sulphur status of soils of agro-ecological regions of India. Fertil. News 1999, 44, 57-60.

Iyenger, B. R. V. and Deb, D. L., 1981, Contribution of soil zinc fractions to plant uptake and fate of zinc applied to the soil. J. Indian Soc. Soil Sci., 25(4): 426-432.

Jat, J. R. and Yadav, B. L., 2006, Different forms of sulphur and their relationship with properties of Entisols of Jaipur district (Rajasthan) under mustard cultivation. J. Indian Soc. Soil Sci., 54: 208-212.

Kajal, D. B., Maya, M. R., Shubham, B. G., and Pallavi, W. G., 2019, Status of different forms of sulphur under intensively soybean growing soils of Savner tehsil, district Nagpur. Inte. J. Chemi. Stud., 7(3): 43-47.

Kulhanek, M., Cerny, J., Balik, J., Vasak, F. and Sedlar, O., 2011, Changes in different sulfur fractions after long term fertilizing. In: Proceeding of the international conference soil, plant and food interactions, 6-8 September, Brno, pp. 215-223.

Narale, S. H., Gajbhiye, B. R. and Gourkede, P. H., 2015, Study of correlation between sulphur fraction with soil properties in soils of Tuljapur, Thahsil of Osmanabad district. Intl. J. Trop. Agri., 33: 2327-2334.

Paritosh, P., Mondal, S. and Ghosh, G. K., 2012, Status of available sulphur in 
surface and subsurface soils of red and lateritic soils of West Bengal. Int. J. Pl. Ani. Environ. Sci., 2(2): 276-280.

Patil, P. L., Pulakeshi H. B. P. and Dasog G. S., 2012, Identification of soil fertility constraints by geographic information system (GIS) technique and response of crops to identified nutrient constraints in northern transitional zone of Karnataka. Proceedings of AIPA, 2012.

Sen, A., Mukhim, J., Debnath, A. and Barman, P., 2017, Distribution of sulphur in some soils of Meghalaya. $J$. Experimental Agri. Interm., 16(6): 1-9.

Shirgire, S. T., Savalia, S. G. and Misal, N. B., 2018, Assessment of Available macro and micronutrient status of coastal Jamnagar district in Saurashtra region of Gujarat. J. Indian Soc. Soil Sci., 66(2): 182-187.

Sparks, 1996, Methods of Soil Analysis Part 3: Chemical Methods. Soil Sci. Soc. America, USA.

Sutariya, G. S., Vora, V. D., Talapada, M. M., Hirpara, D. S, Vekaria, P. D. and Akbari, K. N., 2016, Studies on sulphur forms in soils of Rajkot, Gujarat. J. Sci. Res., 6(1): 61-68.

Tabatabai, M. A., 1982, Sulphur, In Methods of Soil Analysis Ed. Page, A. L., American Soc. Agron., Madison, Wisconsin, USA. Pp 45-46.

\section{How to cite this article:}

Dhanalakshmi, D. and Math, K. K. 2020. Forms and Distribution of Sulphur in Direct Seeded Paddy Growing Soils of Kalaghatagi Taluk of Dharwad District, India. Int.J.Curr.Microbiol.App.Sci. 9(07): 4073-4079. doi: https://doi.org/10.20546/ijcmas.2020.907.478 